\title{
ASESMEN AUTENTIK DALAM ACTIVE LEARNING UNTUK MEMONITOR KEMAJUAN BELAJAR CALON GURU FISIKA
}

\author{
Lia Yuliati \\ Jurusan Fisika FMIPA Universitas Negeri Malang \\ e-mail: liayuliati_um@yahoo.com
}

\begin{abstract}
Abstrak: Penelitian ini bertujuan untuk memonitor kemajuan belajar mahasiswa peserta matakuliah strategi pembelajaran fisika Prodi Pendidikan Fisika FMIPA Universitas Negeri Malang melalui asesmen autentik. Asesmen ini digunakan dalam pembelajaran aktif sebagai salah satu upaya menyiapkan calon guru fisika di abad 21. Kemajuan belajar mahasiswa yang diamati mencakup kemampuan merancang, melaksanakan dan mengevaluasi Rencana Pelaksanaan Pembelajaran (RPP). Penelitian ini merupakan penelitian deskriptif yang dimaksudkan untuk mendeskripsikan proses yang terjadi dalam pembelajaran secara apa adanya melalui pengumpulan data. Penelitian dilaksanakan dalam 3 tahap. Setiap tahap mahasiswa melaksanakan penilaian autentik sesuai dengan materi dan tugas yang diberikan. Instrumen yang digunakan meliputi SAP sebagai panduan pembelajaran, Lembar Kerja Mahasiswa (LKM), butir soal tes, lembar observasi kemampuan melaksanakan pembelajaran, rubrik penilaian tugas-tugas, rubrik penilaian portofolio, jurnal belajar dan panduan wawancara. Pengumpulan data dilakukan dengan pengamatan partisipatif, wawancara dan observasi. Analisis data dilakukan dengan analisis data kualitatif dengan dukungan data kualitatif dan kuatitatif. Hasil penelitian menunjukkan bahwaasesmen autentik dapat digunakan untuk memonitor kemajuan belajar calon guru fisika. Asesmen autentik dapat memonitor hasil belajar mahasiswa dengan mengoptimalkan berbagai aspek kemampuan melalui berbagai aspek penilaian.
\end{abstract}

Kata-kata Kunci: Asesmen autentik, active learning, calon guru fisika, kemajuan belajar

\section{PENDAHULUAN}

Proses pembelajaran merupakan suatu proses interaksi antara guru dan siswa. Proses interaksi antara guru dan siswa inilah yang membutuhkan keterampilan dan pelatihan sebelumnya. Keterampilan dan pelatihan pembelajaran tersebut secara formal diperoleh pada saat seseorang mengikuti pendidikan keguruan di perguruan tinggi. Perguruan tinggi merupakan lembaga yang menyiapkan calon guru agar modal kemampuan dan sikapsikap keguruan calon guru yang terbina secara mantap sejak awal sehingga usaha-usaha lanjutan untuk meningkatkan kualitas guru dengan pembinaan yang berkelanjutan akan semakin mudah. Hal ini menunjukkan bahwa Kualitas guru pertama-tama ditentukan oleh pendidikan calon guru di LPTK (Jalal \& Supriadi, 2001:245).

Sebagai salah satu perguruan tinggi yang menyiapkan calon guru, Universitas Negeri Malang (UM) terlibat langsung untuk melaksanakan pendidikan guru yang berkualitas di abad 21. Salah satu upaya tersebut dilakukan dengan menyelenggarakan matakuliah Strategi Pembelajaran Fisika (SPF) di Program Studi Pendidikan Fisika UM untuk menyiapkan calon guru Fisika. Mata kuliah SPF merupakan mata kuliah yang wajib diikuti oleh semua mahasiswa Program Studi (Prodi) Pendidikan Fisika. Berdasarkan observasi, pada mata kuliah ini mahasiswa memperoleh pengetahuan tentang hakikat IPA, teori-teori belajar, model-model pembelajaran, dan pada akhirnya mahasiswa mampu merancang dan mengimplementasikan RPP pada kegiatan peer teaching. Kegiatan peer teaching merupakan pelatihan wajib bagi calon guru Fisika untuk membentuk guru yang profesional di masa depan.

Seorang guru Fisika yang profesional hendaknya selalu tanggap terhadap perubahan paradigma pembelajaran. Komarudin (dalam Trianto, 2007) menyatakan bahwa perubahan paradigma pembelajaran tersebut adalah orientasi pembelajaran yang semula berpusat pada guru (teacher centered) beralih berpusat pada siswa (student centered); metodologi yang semula lebih didominasi ekspository berganti ke partisipatory; dan pendekatan yang semula lebih banyak bersifat tekstual berubah menjadi kontekstual. Calon guru Fisika seharusnya lebih tanggap pada perubahan paradigma pembelajaran yang semula teacher centered menjadi student centered. Pembelajaran yang berorientasi student centered terdapat pada pembelajaran aktif (active learning). Oleh karena itulah, mahasiswa Program Studi (Prodi) Pendidikan Fisika seharusnya terlibat secara langsung dalam pembelajaran aktif sehingga mampu menerapkan model pembelajaran aktif.

Pembelajaran aktif merupakan salah satu pendekatan pembelajaran yang menekankan pentingnya siswa belajar aktif. Banyak istilah diperkenalkan dan digunakan oleh para ahli pendidikan. Istilah tersebut diantaranya pembelajaran aktif, kreatif, dan menyenangkan (PAKEM), pembelajaran aktif, inovatif, kreatif, dan menyenangkan (PAIKEM), atau PAIKEM gembira dan berbobot (PAIKEM Gembrot). Istilah lain yang dikenal dengan menggunakan bahasa asing adalah Student Centered Learning (SCL). Istilah-istilah ini 
merujuk satu hal yaitu penting pembelajaran yang dapat mengaktifkan belajar siswa dengan cara-cara yang menyenangkan tanpa mengurangi kualitas belajar dan pembelajaran (Yuliati, 2011)

Pembelajaran aktif didefinisikan sebagai metode pembelajaran yang mendorong siswa dalam proses belajar. Pembelajaran aktif mengarahkan siswa untuk melakukan aktivitas belajar bermakna dan berpikir tentang aktivitas yang dilakukannya. Inti dari pembelajaran aktif adalah aktivitas siswa dan penggalian dalam proses belajar. Pembelajaran aktif sering dikontraskan atau dibedakan dengan metode ceramah dimana siswa secara pasif menerima informasi dari guru (Prince, 2001). Menurut Wein (dalam Attard, dkk, 2010:69), pembelajaran aktif adalah suatu pendekatan untuk mendidik siswa dengan memberikan peran yang lebih aktif di dalam proses pembelajaran. Pembelajaran aktif merupakan suatu pendekatan pembelajaran yang memberikan kesempatan kepada siswa untuk berperan lebih aktif dalam proses pembelajarn (mencari informasi, mengolah informasi, dan menimpulkannya, kemudian menerepkan/mempraktikkan) dengan menyediakan lingkungan belajar yang membuat siswa tidak tertekan dan senang melaksanakan kegiatan belajar (Fink, 2009 :71). Ciri umum dalam pembelajaran aktif adalah guru berganti peran, dari peran mempresentasikan materi pelajaran menjadi seorang fasilitator dari proses tersebut.

Sebagai seorang profesional dalam pembelajaran di perguruan tinggi, dosen hendaknya mampu menggunakan asesmen kelas. Kegiatan ini merupakan suatu bentuk kegiatan dosen yang terkait dengan pengambilan keputusan tentang pencapaian kompetensi atau hasil belajar mahasiswa mengikuti proses pembelajaran tertentu. Data yang diperoleh dosen selama proses pembelajaran berlangsung dapat dijaring dan dikumpulkan melalui prosedur dan alat penilaian yang sesuai dengan kompetensi dan hasil belajar yang akan dinilai.

Asesmen berbasis kelas merupakan suatu proses pengumpulan, pelaporan, dan penggunaan informasi tentang hasil belajar mahasiswa dengan menerapkan prinsip-prinsip penilaian, pelaksanaan berkelanjutan, buktibukti autentik, akurat, dan konsisten. Asesmen kelas merupakan suatu proses yang dilakukan melalui langkahlangkah perencanaan, pengumpulan informasi melalui sejumlah bukti yang menunjukkan pencapaian hasil belajar mahasiswa, pelaporan dan penggunaan informasi tentang hasil belajar mahasiswa. Salah satu pendekatan dalam asesmen kelas adalah asesmen autentik, yaitu suatu model asesmen yang dilakukan secara sistematis dan logis untuk mengungkapkan dan menilai mahasiswa secara komprehensif, objektif, akurat, dan sesuai dengan buktibukti autentik yang dimiliki mahasiswa (Arifin, 2009:195).
Asesmen autentik sebagai salah satu bentuk asesmen dalam proses pembelajaran di kelas telah mengalami perkembangan pesat di Amerika Serikat sejak tahun 1990. Asesmen autentik mencakup asesmen portofolio, asesmen kinerja, asesmen produk, dan asesmen poyek. Asemen autentik tersebut telah memberikan kesempatan kepada mahasiswa untuk dapat merefleksikan dan bertanggung jawab pada kemajuan belajar dan cara belajar mahasiswa itu sendiri. Penelitian tentang keefektifan asesmen autentik telak dilakukan oleh Nurani (1996). Hasil penelitian menunjukkan bahwa asesmen autentik merupakan suatu asesmen yang sesuai dengan Satuan Kredit Semester (SKS) yang berlaku bagi pelaksanaan proses pembelajaran di perguruan tinggi. Selain itu, hasil penelitian lain menunjukkan bahwa penggunaan asesmen autentik dapat meningktak hasil belajar yang lebih baik disbanding asesmen lainnya. Berdasarkan penelitian yang telah dilakukan tersebut dan hasil yang telah diperoleh maka asesmen portofolio ini perlu diterapkan pada mata kuliah SPF, karena dengan asesmen ini dapat dilihat dengan jelas perkembangan mahasiswa Prodi Pendidikan Fisika dari waktu ke waktu. Menurut Wiyono dan Sunarni (2009: 23) asesmen portofolio akan dapat berlangsung secara maksimal jika diterapkan pada pembelajaran aktif.

Asesmen autentik dalam bentuk asesmen portofolio sebenarnya telah diimplementasikan pada mata kuliah SPF tahun ajaran 2009/2010. Pada kenyataanya asesmen portofolio belum mencapai kesempurnaan karena tugastugas yang dikumpulkan oleh mahasiswa masih berupa lembaran-lembaran kertas yang dijadikan satu dalam stopmap. Hal ini menyebabkan tugas-tugas mahasiswa tidak terorganisasi secara teratur, banyak diantara tugastugas tersebut yang hilang setelah perkuliahan selama satu semester berakhir. Kebanyakan mahasiswa tidak lagi memiliki tugas-tugas secara lengkap, padahal setiap tugas yang ada dalam portofolio mahasiswa merupakan dokumen penting dari hasil pembelajaran selama satu semester. Selain itu pada asesmen portofolio yang telah ada sebelumnya pada mata kuliah SPF tidak ada bagian refleksi dan evaluasi, sehingga mahasiswa tidak dapat melakukan refleksi dan evaluasi secara tertulis. Pada akhirnya kesulitan yang dialami mahasiswa hanya dipendam dan belum ada kemauan untuk menjadi lebih baik pada pengalaman selanjutnya. Kurangnya bagian refleksi dan evaluasi ini juga menyebabkan dosen pengampu mata kuliah kurang memahami kesulitan mahasiswa selama mengerjakan tugas. Oleh karena itu, asesmen portofolio pada mata kuliah SPF perlu disempurnakan lagi.

Portofolio yang digunakan sebagai asesmen dalam mata kuliah SPF harus mencakup bagian-bagian penting yang ada di dalamnya, yaitu sampul, kata pengantar, daftar isi, tugas-tugas mahasiswa, refleksi, evaluasi diri, dan 
penetapan tujuan (Burke, 2009: 40). Tugas-tugas mahasiswa ini mencakup analisis teori-teori belajar, analisis model-model pembelajaran, dan merancang RPP. Kelengkapan portofolio ini selanjutnya dikumpulkan dalam bentuk buku, sehingga tidak mudah hilang dan lebih terorganisasi. Bagian terpenting dalam asesmen portofolio ini adalah tahap refleksi dan evaluasi, karena pada tahap ini mahasiswa Prodi Pendidikan Fisika dapat menilai sendiri kemampuan mahasiswa dalam belajar, dan mengikuti perkuliahan, sehingga mereka dapat menentukan tindakan untuk meningkatkan kemampuannya sendiri. Mahasiswa Prodi Pendidikan Fisika sebagai calon guru Fisika yang profesional harus memiliki kemampuan merencanakan suatu pembelajaran dengan baik sehingga dapat melakukan pembelajaran dengan baik pula saat melaksanakan tugasnya sebagai guru. Tugas-tugas yang diberikan dan dikerjakan oleh mahasiswa Prodi Pendidikan Fisika harus dilakukan secara bertahap agar dapat diketahui perkembangan dari masing-masing mahasiswa, selain itu mahasiswa juga bisa merefleksi sendiri sampai sejauh mana kemampuannya dalam pengerjaan tugas-tugasnya.

Penelitian ini bertujuan untuk memonitor kemajuan belajar mahasiswa peserta matakuliah Strategi pembelajaran Fisika Prodi Pendidikan Fisika FMIPA Universitas Negeri Malang melalui asesmen autentik. Asesmen ini digunakan dalam pembelajaran aktif sebagai salah satu upaya menyiapkan calon guru Fisika di abad 21. Kemajuan belajar mahasiswa yang diamati mencakup kemampuan merancang, melaksanakan dan mengevaluasi Rencana Pelaksanaan pembelajaran (RPP). Hasil penelitian diharapkan bermanfaat bagi dosen untuk menyempurnakan sistem penilaian matakuliah, dan bagi mahasiswa untuk melatih diri dan memperoleh pengalaman langsung dalam melaksanakan penilaian autentik dalam pembelajaran aktif.

\section{METODE PENELITIAN}

Penelitian ini merupakan jenis penelitian deskriptif. Penelitian dimaksudkan untuk mendeskripsikan proses yang terjadi dalam pembelajaran secara apa adanya melalui pengumpulan data. Data yang dihasilkan merupakan gambaran deskriptif dari proses belajar mahasiswa yang ditempuh dalam perkuliahan Strategi Pembelajaran Fisika, mulai dari perencanaan, pelaksanaan dan evaluasi pembelajaran. Penelitian dilaksanakan dalam 3 tahap. Setiap tahap mahasiswa melaksanakan penilaian autentik sesuai dengan materi dan tugas yang diberikan. Desain penelitian yang dilakukan dapat dilihat pada Gambar 1 .

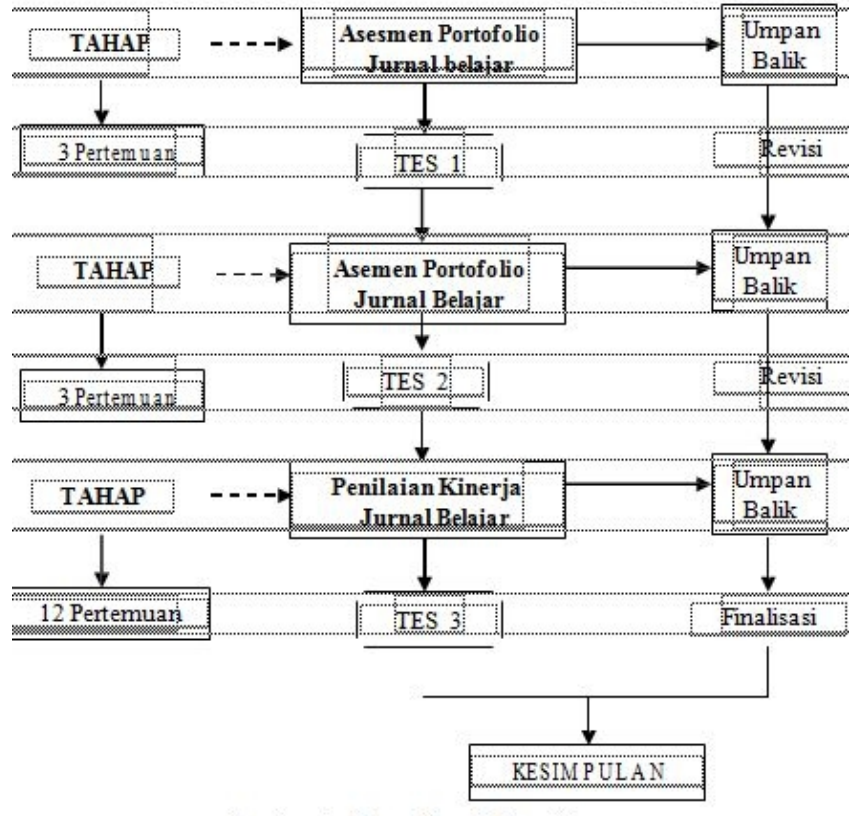

Sambar 1. Bagan Desain Penelitian

Penelitian ini dilaksanakan pada mahasiswa peserta matakuliah Strategi Pembelajaran Fisika di Prodi Pendidikan Fisika FMIPA Universitas Negeri Malang pada tahun ajar 2011/2012. Instrumen penelitian yang digunakan meliputi SAP sebagai panduan pembelajaran, Lembar Kerja Mahasiswa (LKM), butir soal teslembar observasi kemampuan melaksanakan pembelajaran, rubrik penilaian tugas-tugas, rubrik penilaian portofolio, jurnal belajar dan panduan wawancara. Pengumpulan data dilakukan dengan pengamatan partisipatif, wawancara dan observasi. Analisis data dilakukan dengan analisis data kualitatif dengan dukungan data kualitatif dan kuatitatif. Data kualitatif dianalisis dengan reduksi, coding, dan penarikan kesimpulan. Data kuantitatif yang merupakan data pendukung penelitian dianalisis dengan perhitungan sederhana dengan persentase.

\section{HASIL PENELITIAN DAN PEMBAHASAN}

Pembelajaran aktif merupakan pembelajaran yang berpusat pada siswa (student centered). Pembelajaran aktif pada mata kuliah SPF bertujuan agar mahasiswa Prodi Pendidikan Fisika lebih aktif dan inovatif dalam menggali pengetahuannya tentang materi teori belajar, model-model pembelajaran, merancang, melaksanakan dan mengevaluasi pembelajaran. Pembelajaran aktif pada mata kuliah SPF mampu menjadikan mahasiswa bukan hanya aktif secara fisik tetapi juga aktif dalam berpikir. Pada awal pembelajaran, memang mahasiswa masih aktif secara fisik, tetapi setelah dosen memberikan timbal balik, mahasiswa mampu mengklarifikasi kembali jawabannya melalui diskusi kelompok dan dan mulai aktif berpikir.

Ini berarti mahasiswa mampu mengkonstruk pengetahuannnya dan memberikan balikan positif melalui penjelasan atau pertanyaan yang diberikan oleh dosen. 
Sebagaimana pernyataan dari Iskandar (2004: 23) secara umum strategi pengajaran timbal balik dapat menyebabkan pebelajar mampu mengkonstruk pengetahuannya melalui struktur pembelajaran.

Upaya untuk memantau kemajuan belajar dalam matakuliah SPF dilakukan dengan asesmen autentik. Penggunaan asesmen autentik dilakukan secara berkelanjutan sesuai tahap penelitian. Pada tahap 1, asesmen autentik dilakukan dengan asesmen portofolio untuk tugas-tugas berupa tugas karakteristik belajar dan pembelajaran IPA/Fisika, analisis teori belajar, dan jurnal belajar. Pada tahap 2, asesmen autentik dilakukan dengan asesmen portofolio untuk tugas perbedaan perbedaan model, metode, dan pendekatan pembelajaran, karakteristik model pembelajaran Learning Cycle, Direct Instruction, dan Inkuiri, penyusunan Rencana Pelaksanaan Pembelajaran (RPP), dan jurnal belajar. Pada tahap 3, asemen autentik dilakukan dengan asesmen kinerja yang didukung dengan asesmen portofolio, asesmen kinerja, dan jurnal belajar. Diakhir kegiatan, mahasiswa diminta untuk menyusun portofolio. Portofolio yang dimaksud adalah kumpulan dokumen yang meliputi sampul, kata pengantar, daftar isi, tugas- tugas yang telah disepakati sebelumnya (analisis teori belajar, analisis model pembelajaran, dan rancangan RPP), refleksi, evaluasi, harapan dan tujuan, serta jurnal belajar.

Kemampuan mengerjakan tugas kampus dan tugas portofolio mengalami peningkatan dari tahap I ke tahap III. Pada tiap pertemuan mahasiswa semakin terlihat aktif dalam mengikuti perkulihan walaupun pada awalnya muncul kesulitan untuk memahami bahan diskusi.

Mahasiswa tetap aktif menyampaikan pendapatnya melalui diskusi kelompok dan diskusi kelas dengan bimbingan dosen. Hasil penilaian tugas kampus mengalami peningkatan dan penurunan, hal ini bisa terjadi karena pengaruh keadaan kelas pada saat pembelajaran berlangsung.

Hasil penilaian tugas portofolio menunjukkan peningkatan yang baik. Pada tugas analisis teori belajar masih ditemukan mahasiswa yang memiliki jawaban sama dengan mahasiswa lainnya. Hal ini disebabkan waktu yang diperlukan untuk pengumpulan tugas terlalu singkat, sehingga mahasiswa cenderung mencari cara yang lebih singkat untuk mengerjakan tugas. Pada tugas portofolio analisis model pembelajaran hasil nilai yang diperoleh lebih baik dari tugas portofolio sebelumnya. Mahasiswa mampu menunjukkan pengertian tingkat tinggi dari proses pembelajaran dengan menghubungkan antara pengalaman dan teori. Hasil penelitian ini sesuai dengan ciri yang mendasari penyusunan dan penyajian portofolio, bahwa asesmen portofolio dapat menunjukkan pengertian tingkat tinggi dari proses pembelajaran, dengan menggunakan hubungan antara pengalaman-pengalaman praktis dengan masalah- masalah teoritis (Winter dalam Sujiono, 2010: 5).

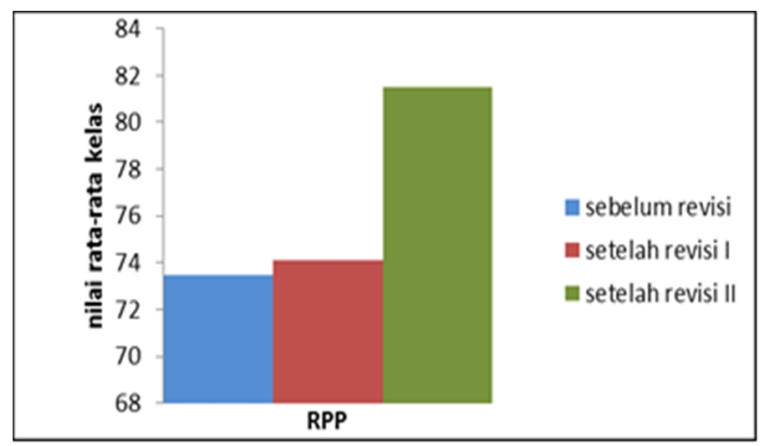

Gambar 2. Grafik nilai rata-rata kelas kemampuan merancang RPP

\begin{tabular}{|c|c|c|c|c|}
\hline \multicolumn{5}{|c|}{ Tabel 1.Kemampluan MerantcallgRPPsetiap Aspek } \\
\hline \multirow[b]{2}{*}{$\mathrm{N}_{0}$} & \multirow[b]{2}{*}{ Aspek yanggDinilai } & \multicolumn{3}{|c|}{ Kemampuan Verancang RPP(\%) } \\
\hline & & $\begin{array}{c}\text { RPP seblum } \\
\text { Rerisi }\end{array}$ & $\begin{array}{l}\text { RPP revisi } \\
\text { pertama (I) }\end{array}$ & $\begin{array}{c}\text { RPP revisi } \\
\text { kedua }\end{array}$ \\
\hline 1 & Merumuskan Indikatoof & 68.46 & 71.72 & 86.61 \\
\hline$?$ & Merumuskan TujulaanPembelajajataln & 60.96 & 64.13 & 79,35 \\
\hline 3 & MenganalisisisMatry'Petubs|ajajaral & 84.78 & 88.04 & 94.57 \\
\hline 4 & MenganalisisisModel Pembelajajaran & 80.43 & 81.52 & 98.91 \\
\hline f & MenyusunLangkah.LangkahModel Pembelajaran & 71,74 & 76.09 & 88.04 \\
\hline 6 & Kemampulan:Memilith Sumber Belajar & 6087 & 70.65 & 88.05 \\
\hline
\end{tabular}

Berdasarkan Tabel 1 dapat diketahui bahwa jumlah mahasiswa yang mampu merancang RPP dari sebelum revisi dan setelah revisi dua kali mengalami kemajuan pada masing- masing aspek. Sebelum revisi mahasiswa mengalami kesulitan dalam merumuskan indikator, merumuskan tujuan pembelajaran, dan memilih sumber belajar yang sesuai dengan Kurikulum Tingkat Satuan Pendidikan. Setelah dilakukan revisi dua kali kesulitan ini dapat diatasi sehingga kemampuan belajar merancang RPP semakin mengalami kemajuan.

Tugas penyusunan portofolio yang dikerjakan oleh mahasiswa dikumpulkan satu minggu setelah praktik peer teaching. Bagian-bagian yang harus ada dalam tugas portofolio adalah sampul, kata pengantar, daftar isi, kumpulan tugas, refleksi, evaluasi, tujuan dan harapan, serta jurnal belajar. Kumpulan tugas meliputi analisis teori belajar, analisis model-model pembelajaran, dan RPP sebelum dan setelah revisi. Aspek penilaian portofolio ini meliputi penugasan, tampilan, pengorganisasian, dan jurnal belajar. Setiap aspek dinilai dengan bobot skor yang berbeda-beda. Hal ini sesuai dengan pernyataan dari Muijs \& Reynold (2008: 119) bahwa skor yang diperoleh pada tugas portofolio memiliki bobot yang berbeda untuk setiap aspek, tergantung dari tingkat kesulitan dari pengerjaan masing- masing aspek. 
Pada penyusunan portofolio ini, mahasiswa cenderung menggunakan teknik penyusunan yang sederhana. Lebih dari 50\% tugas mahasiswa belum terlihat adanya tampilan yang kreatif dan menarik, misalnya ada penulisan tugas yang tidak diketik, ukuran kertas yang tidak sama, dan susunan sampul yang masih sederhana. Hal ini disebabkan karena tidak adanya pemberitahuan tentang bobot masing-masing aspek dalam portofolio. Melalui asesmen portofolio ini dapat diamati perkembangan nilai mahasiswa dari waktu ke waktu serta mendemonstrasikan tingkat pemahaman dan keterampilan mahasiswa. Hal ini sesuai dengan pernyataan dari Sujiono (2010: 9) bahwa portofolio dapat meningkatkan proses pengukuran suatu tingkat keterampilan dan pemahaman mahasiswa, mendukung tujuan pembelajaran, dan pertumbuhan selama kurun waktu tertentu.

Penyusunan portofolio ini dinilai dengan rubrik penilaian portofolio. Di dalam portofolio ini terdapat bagian yang sangat penting dan menjadi karakter khusus dari asesmen portofolio yaitu adanya refleksi dan evaluasi diri. Pernyataan ini membuktikan bahwa melalui penilaian portofolio mahasiswa mampu merefleksi pembelajarannya sendiri. Sebagaimana yang dinyatakan oleh Arends (2008: 247), portofolio diberi skor dengan menggunakan rubrik penilaian dan mengharuskan mahasiswa menyiapkan portofolionya sehingga dapat merefleksikan pembelajarannya sendiri.

Portofolio yang telah dinilai oleh dosen selanjutnya dikembalikan lagi kepada mahasiswa. Pengembalian tugas pada asesmen portofolio ini menjadikan mahasiswa cenderung membandingkan hasil kerjanya dengan hasil kerja temannya, sehingga mahasiswa dapat melihat kemampuannya menyusun portofolio dibandingkan dengan teman sekelasnya. Kecenderungan ini dapat berdampak positif pada peningkatan kemampuan mahasiswa karena mahasiswa termotivasi untuk hasil penyusunan portofolio yang lebih baik. Hal ini sebenarnya tidak sesuai dengan prinsip confidentiality (kerahasiaan bersama) pada asesmen portofolio. Penerapan prinsip confidentiality ini berdampak positif bagi mahasiswa, karena kelemahannya dalam materi tertentu menjadi rahasia antara dosen dan mahasiswa yang bersangkutan dan tidak dipublikasikan. Selain itu prinsip confidentiality pada asesmen portofolio juga memiliki dampak negatif yaitu mahasiswa tidak dapat membandingkan pekerjaannya dengan pekerjaan temannya, sehingga kurang termotivasi untuk meningkatkan penyusunan portofolionya.

Tugas portofolio yang dikerjakan oleh mahasiswa dikumpulkan satu minggu setelah praktik peer teaching. Bagian-bagian yang harus ada dalam tugas portofolio adalah sampul, kata pengantar, daftar isi, kumpulan tugas, refleksi, evaluasi, tujuan dan harapan, serta jurnal belajar. Kumpulan tugas meliputi analisis teori belajar, analisis model-model pembelajaran, dan RPP sebelum dan setelah revisi. Aspek penilaian portofolio ini meliputi penugasan, tampilan, pengorganisasian, dan jurnal belajar. Masing-masing aspek yang dinilai memiliki bobot yang berbeda, untuk penugasan $25 \%$, tampilan $10 \%$, pengorganisasian $45 \%$, dan jurnal belajar $20 \%$. Penugasan dalam asesmen portofolio terdiri dari analisis teori belajar, analisis model pembelajaran, dan rancangan RPP. Aspek yang dinilai dalam tampilan portofolio meliputi sampul, ukuran kertas, penulisan, dan penyusunan tugas. Aspek yang dinilai pada bagian pengorganisasian adalah kelengkapan isi (kata pengantar, daftar isi, kumpulan tugas, refleksi, evaluasi, dan penetapan tujuan) dan ketepatan waktu pengumpulan. Pada jurnal belajar, aspek yang dinilai adalah tulisan mahasiswa tentang pengalaman yang diperoleh, hal yang didapat, dan hal yang perlu ditambahkan pada tiap pertemuan.

Pemantauan kemajuan belajar mahasiswa juga dilakukan dengan tes di akhir tahap penelitian. Hasil nilai tes juga mengalami peningkatan dari tahap 1 ke tahap III. Peningkatan hasil penilaian ini tidak lepas dari proses pembelajaran sebelumnya. Ini berarti bahwa portofolio sangat berperan dalam penilaian proses belajar dan hasil belajar. Ketuntasan belajar mahasiswa yang dilihat melalui hasil tes tertulis ini menyatakan bahawa kemajuan belajar mahasiswa semakin meningkat, hal ini berarti asesmen portofolio pada pembelajaran aktif telah berhasil mendeskripsikan kemajuan belajar mahasiswa. Sebagaimana yang dinyatakan oleh Linn dan Gronlund (dalam Kaira \& Wells 2009: 31) bahwa asesmen portofolio dapat digunakan untuk berbagai kepentingan, seperti membantu rencana pembelajaran, menguji hasil belajar mahasiswa, dan mendeskripsikan perkembangan kemajuan belajar mahasiswa.

Respon mahasiswa terhadap asesmen portofolio pada pembelajaran aktif dalam mata kuliah SPF dapat diketahui melalui wawancara. Hal-hal yang menjadi topik wawancara adalah tentang kesesuaian asesmen portofolio pada mata kuliah SPF, kelebihan dan kelemahan asesmen portofolio, serta proses pengerjaan portofolio. Melalui wawancara ini dapat diketahui efektifitas asesmen portofolio pada mata kuliah SPF, sehingga dapat meningkatkan kualitas pembelajaran pada tahun ajaran selanjutnya. Data hasil wawancara dapat dilihat pada Tabel 2

Tabel 2. Respons Mahasiswa terhadap Asesmen Autentik

\begin{tabular}{|r|l|l|}
\hline No & \multicolumn{1}{|c|}{ Kategori } & \multicolumn{1}{c|}{ Respon Mahasiswa } \\
\hline 1. & Kesesuaian & Asesmen portofolio \\
& & sesuai untuk mata \\
& & kuliah SPF, karena \\
& & Dapat mengetahui \\
& & kemampuan sendiri, \\
\hline
\end{tabular}




\begin{tabular}{|c|c|c|}
\hline & & $\begin{array}{l}\text { dapat memperoleh hasil } \\
\text { yang lebih baik setelah } \\
\text { melakukan revisi, dan } \\
\text { dapat meningkatkan } \\
\text { kemampuan merancang } \\
\text { RPP yang baik. }\end{array}$ \\
\hline 2. & $\begin{array}{l}\text { Kelebihan dan } \\
\text { kelemahan asesmen } \\
\text { portofolio }\end{array}$ & $\begin{array}{l}\text { - Kelebihan Asesmen } \\
\text { Portofolio : } \\
\text { Mahasiswa lebih } \\
\text { antusias dalam } \\
\text { mengikuti perkuliahan } \\
\text { dan mengerjakan } \\
\text { tugas, dapat digunakan } \\
\text { untuk merefleksi } \\
\text { kemampuan } \\
\text { belajarnya dan } \\
\text { mengevaluasi } \\
\text { perkuliahan, memiliki } \\
\text { arsip berupa kumpulan } \\
\text { tugas untuk } \\
\text { pembelajaran lebih } \\
\text { lanjut, memiliki } \\
\text { semangat untuk } \\
\text { belajar, memiliki } \\
\text { pengalaman baru } \\
\text { menyusun portofolio, } \\
\text { karena ini merupakan } \\
\text { pengalaman pertama } \\
\text { selama mengikuti } \\
\text { pembelajaran, dan } \\
\text { dapat meningkatkan } \\
\text { kemampuan } \\
\text { menyusun kata- kata } \\
\text { dengan baik dan tidak } \\
\text { ambigu Kelemahan Asesmen } \\
\text { Portofolio: Mahasiswa } \\
\text { beranggapan waktu } \\
\text { yang digunakan } \\
\text { untuk penyusunan } \\
\text { portofolio terlalu } \\
\text { singkat, mahasiswa } \\
\text { sulit membedakan } \\
\text { antara refleksi dan } \\
\text { evaluasi, dan } \\
\text { mahasiswa } \\
\text { beranggapan bahwa } \\
\text { untuk penyusunan } \\
\text { portofolio terlalu berat. }\end{array}$ \\
\hline 3. & Proses Pengerjaan & $\begin{array}{l}\text { Dosen memberikan } \\
\text { petunjuk sebelum } \\
\text { pengerjaan portofolio } \\
\text { - Dosen menjelaskan } \\
\text { kepada mahasiswa } \\
\text { bagian-bagian yang } \\
\text { harus ada dalam } \\
\text { portofolio, yaitu: } \\
\text { sampul, kata } \\
\text { pengantar, daftar isi, } \\
\text { kumpulan tugas, }\end{array}$ \\
\hline
\end{tabular}

\begin{tabular}{|l|l|}
\hline & jurnal belajar, refleksi, \\
dan evaluasi \\
- Dosen mengadakan \\
revisi untuk tugas \\
& merancang RPP baik \\
& sebelum implementasi \\
& maupun setelah \\
& implementasi \\
\hline
\end{tabular}

Mahasiswa sebagai responden menyatakan ketertarikan terhadap mata kuliah Strategi Pembelajaran Fisika, karena selalu menerapkan pembelajaran aktif yang tidak membosankan. Mahasiswa juga sangat terkesan dengan asesmen portofolio yang diterapkan pada mata kuliah ini, karena ini merupakan pengalaman pertama mahasiswa dalam menyusun tugas portofolio. Melalui asesmen portofolio, mahasiswa lebih antusias dalam mengikuti perkuliahan, mahasiswa memiliki semangat untuk belajar karena mau tidak mau mahasiswa harus bekerja keras untuk mendapatkan hasil terbaik pada nilai tugas portofolionya.

Asesmen portofolio dapat meningkatkan semangat belajar mahasiswa untuk menggali pengetahuan lebih dalam lagi tentang teori belajar, model pembelajaran, cara merancang dan mengimplementasikan RPP, serta cara merefleksi dan mengevaluasi belajar dan perkuliahan. Dengan adanya asesmen portofolio ini mahasiswa mempunyai dokumentasi pribadi pada mata kuliah SPF, karena tugas-tugas dapat tersusun secara rapi dan dapat dipelajari kembali, selain itu mahasiswa juga bisa meningkatkan kemampuan menyusun kata-kata dengan baik, tidak menimbulkan penafsiran ganda. Sebagaimana yang dinyatakan oleh Arifin (2009: 200) bahwa asesmen portofolio dapat mendokumentasikan hasil pembelajaran dan meningkatkan kemampuan refleksi diri.

Asesmen autentik sangat efektif diterapkan pada mata kuliah SPF, karena mahasiswa merasa mempunyai pegangan untuk bekal mengajar nantinya. Asesmen autentik sangat tepat jika dilaksanakan pada mata kuliah pembelajaran, misalnya Belajar dan Pembelajaran, Keterampilan Dasar Mengajar, dan Pengantar Pendidikan karena pada mata kuliah pembelajaran terdapat banyak materi yang penting dan wajib diketahui oleh calon guru, selain itu pada mata kuliah pembelajaran mahasiswa dapat menyumbangkan gagasan yang terkait dengan pendidikan. Sebagaimana yang dinyatakan oleh Winter (dalam Sujiono, 2010: 5) bahwa penyajian portofolio sebaiknya berisikan gagasan/ ide dan argumentasi yang berkenaan dengan pendidikan dan batasan dari suatu topik yang dikaji. Asesmen portofolio dapat menginformasikan kepada mahasiswa bagian-bagian mana yang perlu diperbaiki dan yang perlu ditingkatkan melaui pelakasanaan revisi. 
Menurut pengakuan para responden, dalam menyusun portofolio ini mereka mengalami kesulitan membedakan antara refleksi dan evaluasi, karena keduanya memiliki pengertian yang hampir sama. Penyusunan portofolio membutuhkan keterampilan dalam merangkai kalimat dan membutuhkan waktu yang lebih lama dan kerja lebih ekstra daripada tugas-tugas kuliah yang lain. Hal ini sesuai dengan pernyataan yang dikemukakan oleh Arifin (2009: 206) tentang kekurangan asesmen portofolio yaitu membutuhkan waktu yang tidak singkat dan kerja ekstra. Untuk tugas penyusunan portofolio telah dibuat kesepakatan pada pertemuan pertama. Pada tugas menanganalisis teori dan model pembelajaran telah dilakukan pada pertemuan ketiga dan keenam. Satu minggu setelah implementasi RPP mahasiswa wajib mengumpulkan tugas portofolio. Mahasiswa merasa tugas portofolio terlalu berat, hal ini disebabkan karena adanya kecenderungan mahasiswa mengerjakannya mendekati batas waktu pengumpulan.

\section{KESIMPULAN}

Hasil penelitian menunjukkan bahwa asesmen autentik dapat digunakan untuk memonitor kemajuan belajar calon guru Fisika. Asesmen portofolio memberi meotivasi dan kesempatan pada mahasiswa untuk selalu memperbaiki karyanya yang meliputi tugas-tugas belajar dan penyusunan RPP sehingga terwujud karya terbaik. Asesmen kinerja dalam pelaksanaan pembelajaran member kesempatan pada mahasiswa untuk melakukan self assessment dan peer assessment sehingga mahasiswa terbiasa untuk selalu melakukan refleksi. Jurnal belajar Dengan demikian, asesmen autentik dapat memonitor hasil belajar mahasiswa dengan mengoptimalkan berbagai aspek kemampuan melalui berbagai aspek penilaian.

\section{DAFTAR PUSTAKA}

Arends, R. I. 2008. Learning To Teach (Belajar Untuk Mengajar) (buku 1). Terjemahan Helly P. S \& Sri M. S.Yogyakarta: Pustaka Pelajar

Arifin, Z. 2009. Evaluasi Pembelajaran. Bandung: Remaja Rosda Karya.

Attard, A, Iorio, E. D, Geven, K \& Santa, R. 2010. StudentCentered Learning-Toolkit for Students, Staf and Higher Education Institutions. Berlin: Lifelong Education Programme.

Burke, K. 2009. How To Assess Authentic Learning Fifth Edition. California: Corwin A Sage Company.

Fink, 1.D. 1999. Active Learning. Tokyo: The University of Oklahoma Instructional Development Program

Jalal, F. \& Supriadi, D. (editor). 2001. Reformasi Pendidikan dalam Konteks Otonomi Daerah. Jakarta: Departemen Pendidikan Nasional, Bappenas Adicita Karya Nusa.
Kaira, L.T \& Wells, C. S. 2009. Penyusunan dan Pengujian Penilaian Kelas. Terjemahan Rahmawati \& Urip P. Bandung: Universitas Padjadjaran Bandung.

Muijs, D. \& Reynolds D. 2008. Effective Teaching (Teori dan Aplikasi). Terjemahan Helly P. S \& Sri M. S.Yogyakarta: Pustaka Pelajar

Prince, M 2004, Does Active Learning Work? A Review of the Research. Journal of Engineering Education. 93 (3) 223-231.

Sujiono, Y. N. 2010. Mengajar dengan Portofolio. Jakarta: Indeks.

Wiyono, B.B. \& Sunarni. 2009. Evaluasi Program Pendidikan dan Pembelajaran. Malang: FIP UM.

Yuliati, L. 2011. Restrukturisasi Pendidikan dengan Active Learning. Jurnal TEQIP. Tahun II No 1 Mei 2011 